\title{
OBTENÇÃO DE DNA DE ESPÉCIES DE PLANTAS OCORRENTES NOS LIMITES DO SEMIÁRIDO
}

\section{Andreza Oliveira Matos'; Reyjane Patricia de Oliveira²; Ariadne de Araújo Sampaio $^{3}$ Iasmin Laiane de Castro Oliveira ${ }^{4}$}

\author{
1. Bolsista PIBIC/FAPESB, Graduando em Licenciatura em Ciências Biológicas, Universidade Estadual de Feira de \\ Santana, e-mail: aandreza.oliveira@ hotmail.com \\ 2. Orientador, Departamento de Ciências Biológicas, Universidade Estadual de Feira de Santana, e-mail: \\ rpatricia@uefs.br \\ 3. Bolsista PIBIC/CNPq, Departamento de Ciências Biológicas, Universidade Estadual de Feira de Santana, e-mail: \\ ari.biologiauefs@gmail.com \\ 4.Pós-graduação em Recursos Genéticos Vegetais, Departamento de Ciências Biológicas, Universidade Estadual de \\ Feira de Santana, e-mail: iasminlaiane@gmail.com
}

PALAVRAS-CHAVE: Flora, Nordeste, Banco de DNA.

\section{INTRODUÇÃO}

O Semiárido envolve a região Nordeste do Brasil e norte de Minas Gerais ocupando cerca de $900.000 \mathrm{Km}^{2}$ incluindo parte dos Estados do Piauí, Ceará, Rio Grande do Norte, Paraíba, Pernambuco, Alagoas, Sergipe, Bahia e Minas Gerais (Queiroz et al. 2006). Essa região exibe tipos de vegetação variados, condicionados por diferenças hídricas e geomorfológicas, como caatingas nas depressões interplanálticas, e nas áreas com altitudes mais elevadas (conhecidas regionalmente como "Chapadas") ocorrem campos rupestres, cerrados e florestas, com grande variação do ponto de vista florístico e fitofisionômico, assim como nos aspectos morfofuncionais da vegetação (Giulietti \& Queiroz 2006).

Tais variações proporcionam grande riqueza florística, como demonstrado nos inventários que estão sendo realizados no âmbito da rede PPBIO Semiárido há anos. Mas existem áreas ainda mal coletadas ou carentes de informações sobre as floras locais, sendo consideradas promissoras para o desenvolvimento de inventários. $\mathrm{Na}$ edição atual do PPBIO foram selecionadas como prioritárias as regiões entre Abaíra e Itaetê, na Chapada Diamantina, Bahia; a região do sertão de Quixeramobim, com ênfase no município de Quixadá, no Ceará; e a região do baixo Jaguaribe, inserida na Chapada do Apodi, na divisa entre os estados do Rio Grande do Norte e Ceará.

Além do desconhecimento sobre floras locais, a conservação das espécies ocorrentes nesse e em outros biomas do Brasil tem sido uma preocupação constante, segundo Forzza et al. (2012). Por isso uma atenção crescente tem sido destinada a melhor qualificá-las e quantificá-las através de catalogações mais adequadas, incluindo delimitações mais acuradas das espécies, estimativas dos seus níveis de diversidade e uso de tais informações para sua conservação e manejo.

Nesse sentido, análises baseadas no DNA das amostras são particularmente úteis e subsidiam os estudos florísticos e taxonômicos clássicos, com uso conhecido na determinação de relacionamentos filogenéticos, estrutura populacional e eventos históricos das populações (Frankham et al. 2002), além dos estudos de DNA barcoding, que se servem à identificação molecular de espécimes (van den Berg 2005), especialmente em grupos com taxonomia complicada.

Os estudos que envolvem dados moleculares em plantas do semiárido ainda podem ser considerados muito limitados e o DNA total de muitas espécies nunca foi armazenado em qualquer coleção desse tipo, sendo o foco principal do presente plano 
de trabalho. Assim, o objetivo principal desse trabalho é apresentar os avanços em relação à obtenção de amostras de DNA de plantas do Semiárido, através da extração das amostras coletadas como parte da rede PPBIO.

\section{METODOLOGIA}

As amostras de folhas e/ou flores oriundas de coletas realizadas nas áreas selecionadas para os inventários na edição atual da rede PPBIO Semiárido, além de outras amostras coletadas em edições anteriores do projeto, foram mantidas em sílica gel (Chase \& Willis 1990) até o momento da extração. Viagens de coleta também foram realizadas mais recentemente, a fim de obter amostras de grupos taxonômicos pouco representativos em nossas coleções (Fig. 1). Todas as amostras possuem voucher no herbário HUEFS, as quais estão sendo identificadas como parte dos inventários do projeto PPBIO Semiárido e serão revisadas no Workshop de identificação promovido pela coordenaçãa do PPBIO/Semiárido.

O DNA total das amostras foi extraído no Laboratório de Sistemática Molecular da UEFS (LAMOL/UEFS) a partir do método de Doyle \& Doyle (1987), com adaptações para microtubos. Além do protocolo padrão estabelecido no LAMOL, também foi testado o uso do macerador automático TissueLyser II. Após a extração as mesmas foram armazenadas a temperaturas muito baixas (ca. $-80^{\circ}$ ), podendo ser mantidas durante muitos anos.

As amostras foram quantificadas em gel de agarose a $1 \%$, para verificação da ocorrência ou não de bandas, indicando a concentração e qualidade do DNA extraído. Em conseguinte, cada amostra foi cadastrada e incorporada à Coleção de DNAs do LAMOL que abriga atualmente o maior banco de DNAs de plantas no Brasil, com grande representatividade de espécies do Semiárido.

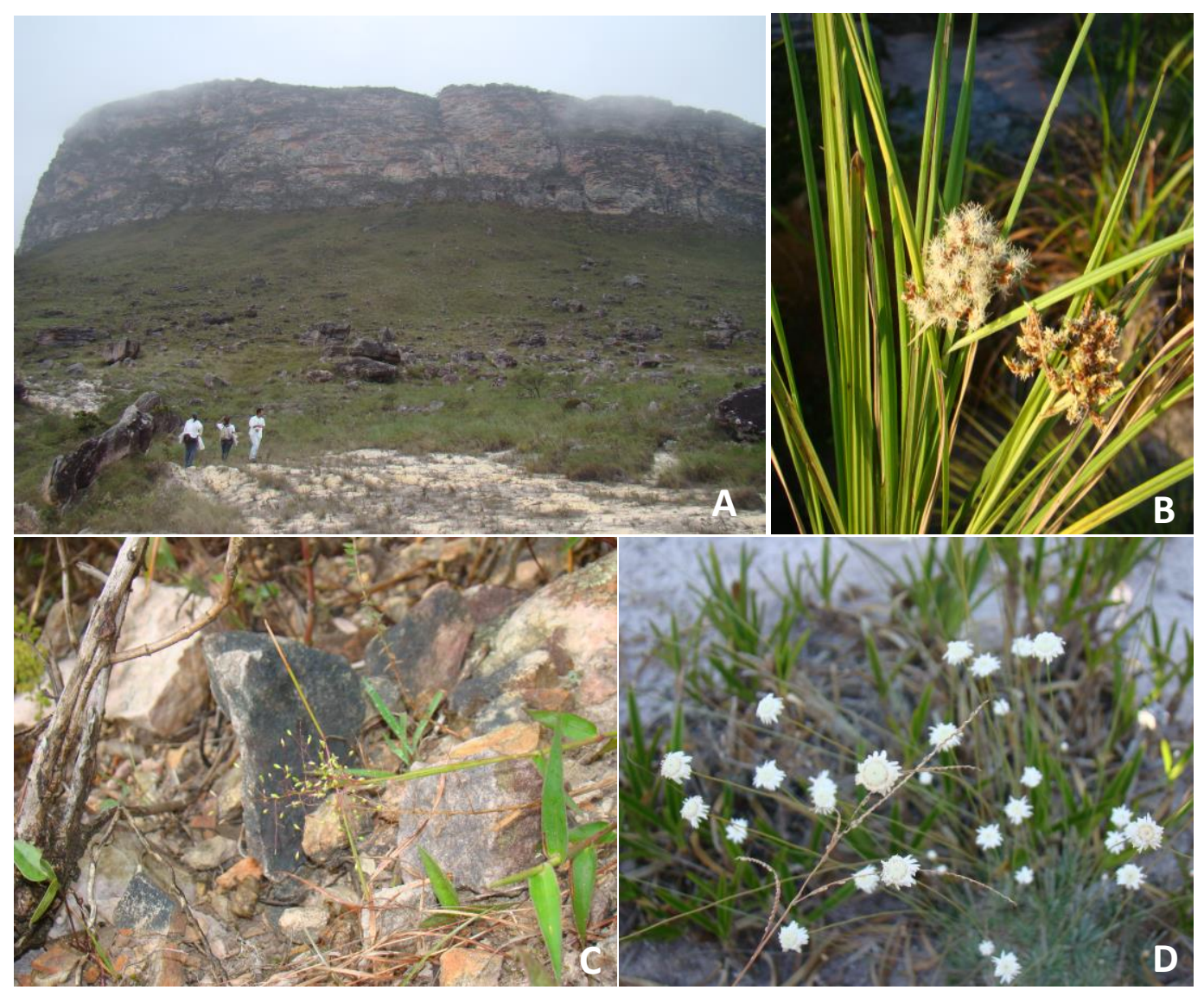


Figura 1. A. Serra do Esbarrancado, Mucugê, Chapada Diamantina, Bahia. B-D.: Representantes de Monocots coletados na região e cujo DNA total encontra-se extraído: B. Cyperaceae, C. Poaceae (Dichanthelium), D. Eriocaulaceae (Syngonanthus).

\section{RESULTADOS}

Todas as amostras em sílica coletadas como parte da edição atual do PPBIO semiárido encaminhadas para o LAMOL tiveram seu DNA total extraído, quantificado e incorporado ao banco de DNAs. O número de novas amostras é expressivo, correspondendo a ca. $20 \%$ das plantas coletadas nessa edição do projeto até o momento. Ao todo foram extraídas 410 amostras, a grande maioria apresentando DNA em grande quantidade e com a qualidade desejável para o desenvolvimento de estudos moleculares, a exemplo de estudos filogenéticos e de genética de populações.

Dentre as localidades onde foram realizadas coletas para o PPBIO, apenas cinco apresentaram coletas específicas para DNA, todas elas na Chapada Diamantina, Bahia: Abaíra, Andaraí, Mucugê, Palmeiras e Rio de Contas. Dentre elas, a área com maior número de amostras coletadas foi Abaíra (187 amostras), seguida por Palmeiras (73 amostras). A área com menor número foi Rio de Contas (29 amostras), seguida por Mucugê (59 amostras).

As famílias com maior representatividade entre as amostras extraídas foram Poaceae (62 amostras), Leguminosae (37 amostras), Asteraceae (30 amostras) e Melastomataceae (23 amostras). Para Abaíra, as famílias mais representadas foram Poaceae (34 amostras), Leguminosae e Euphorbiaceae (18 amostras cada); para Andaraí, Cyperaceae ( 7 amostras) e Asteraceae $(6$ amostras) foram as mais representativas; em Mucugê, Leguminosae e Asteraceae (7 amostras), além de Poaceae (6 amostras); em Palmeiras, Poaceae (12 amostras) e Asteraceae (7 amostras); e em Rio de Contas, Asteraceae ( 7 amostras) e Melastomataceae (6 amostras) foram as mais numerosas (Fig. 2).

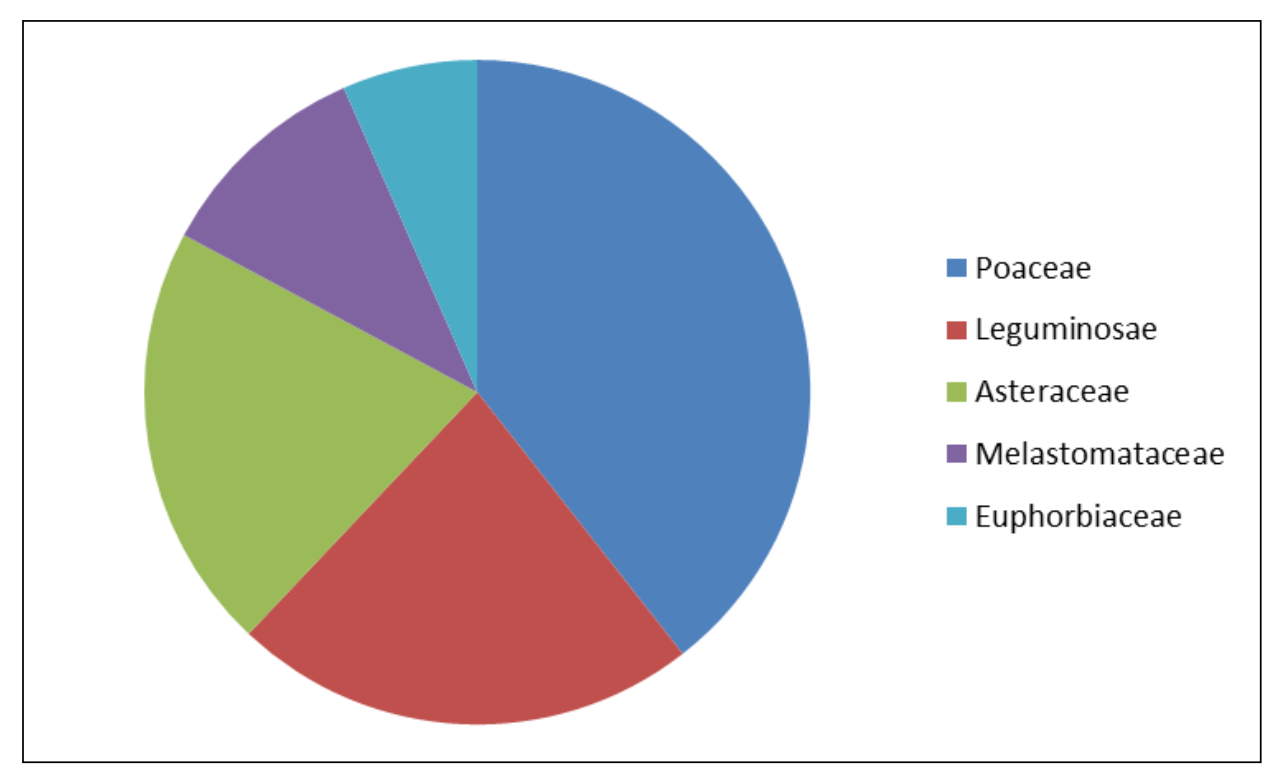

Figura 2- Famílias de Angiospermas com maior número de amostras coletadas no âmbito da edição vigente do PPBIO Semiárido, cujo DNA total foi extraído e depositado no banco de DNAs do LAMOL/UEFS. 


\section{CONCLUSÃO}

O número de amostras coletadas para extração e inserção em banco de DNAs tem crescido bastante, mas ainda foi detectada uma baixa representatividade em diferentes grupos plantas em determinadas áreas consideradas prioritárias da rede PPBIO Semiárido. Desse modo, considera-se necessária a continuação de coletas que garantam a aquisição de mais materiais específicos para extração de DNA, tendo em vista a grande utilidade que esses dados podem ter. Assim, a extração de tais amostras é uma grande contribuição para a complementação do conhecimento a respeito da biodiversidade do Semiárido, subsidiando ações futuras que aprofundem os estudos a respeito da diversidade e possíveis formas de conservação e manejo das plantas da região.

\section{REFERÊNCIAS BIBLIOGRÁFICAS}

CHASE, M. W. \& HILLS, H. G. 1991. Silica gel: an ideal material for field preservation of leaf samples for DNA studies. Taxon 40: 215-220.

DOYLE, J. J. \& DOYLE, J. L. 1987. A rapid DNA isolation method for small quantities of fresh tissues. Phytochemistry Bullettin of Botanical Society of America 19: 11-15.

FORZZA, R. C., BAUMGRATZ, J. F., BICUDO, C. E., CANHOS, D. A., CARVALHO, COELHO, A. A., NADRUZ, M., COSTA, A. F., HOPKINS, D. P., MICHAEL G. LEITMAN, PAULA M., LOHMANN, L. G., LUGHADHA, E., MAiA, L. C., MARTinelli, G. M., MORIM, M., PEIXOTO, M. P., PIRANI, J. R., PRADO, J., QUEIROZ, L. P., SOUZA, S., SOUZA, V. C., STEHMANN, J. R., SYLVESTRE, L. S., WALTER, B. M. T. ET AL. 2012. New Brazilian Floristic List Highlights Conservation Challenges. Bioscience (Washington) 62: 39-45.

FRANKHAM R, BALLOU, J. D. \& BRISCOE, D. A. 2002. Introduction to conservation genetics. Cambridge University Press.

GIULIETTI, A. M. \& QUEIROZ, L. P. (Org.). 2006. Instituto do Milênio do Semiárido. 1. ed. Recife: APNE, 2000p.

QUEIROZ, L.P.; CONCEIÇÃO, A.A. \& GIULIETTI, A.M. 2006. Nordeste semi-árido: caracterização geral e lista das fanerógamas. In: Diversidade e caracterização das fanerógamas do semi-árido brasileiro. Recife, Associação Plantas do Nordeste. Vol I. 